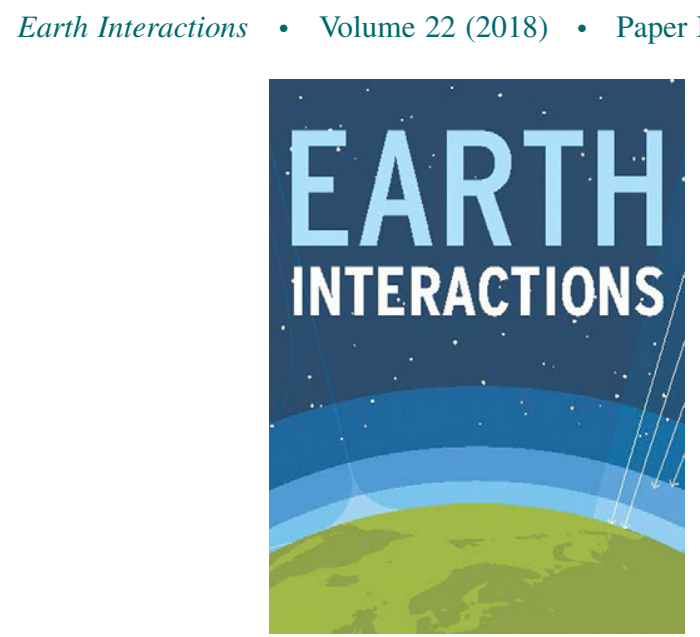

(C) 2018 American Meteorological Society. For information regarding reuse of this content and general copyright information, consult the AMS Copyright Policy (www.ametsoc.org/PUBSReuseLicenses).

\title{
Drought and Land-Cover Conditions in the Great Plains ${ }^{\star}$
}

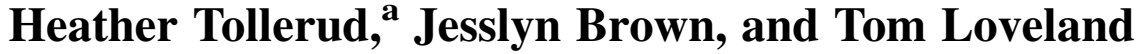

Earth Resources Observation and Science Center, U.S. Geological Survey, Sioux Falls, South Dakota

\section{Rezaul Mahmood}

High Plains Regional Climate Center, School of Natural Resources, University of Nebraska-Lincoln, Lincoln, Nebraska

\section{Norman Bliss}

ASRC Federal InuTeq LLC, and Earth Resources Observation and Science Center, U.S. Geological Survey, Sioux Falls, South Dakota

Received 2 October 2017; in final form 24 July 2018

\begin{abstract}
Land-atmosphere interactions play a critical role in the Earth system, and a better understanding of these interactions could improve weather and climate models. The interaction among drought, vegetation productivity, and land cover is of particular significance. In a semiarid environment, such as the U.S. Great Plains, droughts can have a large influence on the productivity of agriculture and grasslands, with serious environmental and economic impacts.
\end{abstract}

Supplemental information related to this paper is available at the Journals Online website: https://doi.org/10.1175/EI-D-17-0025.s1.

${ }^{a}$ Corresponding author: Heather Tollerud, htollerud@usgs.gov

DOI: 10.1175/EI-D-17-0025.1 
Earth Interactions - Volume 22 (2018) - Paper No. 17 • Page 2

Here, we used the vegetation drought response index (VegDRI) drought indicator to investigate the response of vegetation to weather and climate for landcover types in the Great Plains in the United States from 1989 to 2012. We found that analysis that focused on land-cover types within ecoregion divisions provided substantially more and land-cover-based detail on the timing and intensity of drought than did summarizing across the entire Great Plains region. In the northern Great Plains, VegDRI measured more frequent drought impacts on vegetation in the western ecoregions than in the eastern ecoregions. Across the ecoregions of the Great Plains, drought impacts on vegetation were more commonly found in grassland than in cropland. For example, in the "Northwestern Great Plains" ecoregion (which encompasses areas of Montana, Wyoming, North Dakota, South Dakota, and Nebraska), grassland and nonirrigated cropland were observed in VegDRI to have historical fractional drought coverages in the growing season of $17 \%$ and $11 \%$, respectively.

KEYWORDS: $\quad$ Land surface; Drought; Vegetation; Remote sensing; Atmosphereland interaction; Vegetation-atmosphere interactions

\section{Introduction}

It is well known that land use and land cover (LULC) play an important role in Earth's climate through forcing and feedback mechanisms. Many prior studies have documented ways that LULC and changes in LULC influence climate at local, regional, and global scales (e.g., Pielke et al. 2011; Mahmood et al. 2014). However, there is a relative shortage of systematic and synoptic investigations focused on the influence of weather and climate variation on LULC (Reid et al. 2000; Fensham et al. 2009; Tomer and Schilling 2009). The extent to which LULC and associated vegetation patterns are affected by short-term weather events such as floods and severe storms, medium-term events such as drought or periods of high precipitation, or long-term trends associated with climate change is not well known.

The Third National Climate Assessment (NCA3) Report (Melillo et al. 2014) identified LULC change as a "cross cutting" issue of future climate change studies. Recent trends in LULC change in the United States were documented by Brown et al. (2014) in the NCA3 and by Loveland et al. (2012) in a scientific technical report for the NCA3. The NCA3 called for sustained assessment, and it has been suggested that there is a need for ongoing assessment of trends in LULC change in the United States (Loveland et al. 2012; Loveland and Mahmood 2014). These authors recommended a focus on identifying and understanding 1) climateLULC change connections, 2) sectors and regions that are most affected by weather and climate variability, 3) regions that are most vulnerable to climate change, 4) spatial and temporal dimensions of the processes that affect vulnerable regions, and 5) how land-use practices adapt to climate change (Loveland and Mahmood 2014). The importance of the climate-LULC change relationship was further highlighted by recommendations that global- and national-scale LULC change policies need to be climate relevant and coherent (Mahmood et al. 2016). In a practical sense, projected weather and climate variation and change will impact LULC practices and conditions. This complicates natural resources management decisions, since adopting land-use practices to support mitigation of climate impacts might compete with the goal of adapting LULC to short-, medium-, or 
Earth Interactions • Volume 22 (2018) • Paper No. 17 • Page 3

long-term weather and climate changes to reduce adverse impacts or increase land productivity.

Vegetation changes are an important component of LULC change, and so it is crucial to investigate the influence of weather and climate on vegetation in the context of LULC. Drought impacts on vegetation are particularly critical, since drought can be a driver of both LULC stability and change. Hydroclimatic regime governs the response of vegetation or land cover to water stress, and water limitations or drought conditions impact the health and state of vegetation. For example, while vegetation of both arid and humid biomes responds to water stress on relatively short time scales, vegetation of semiarid or subhumid biomes may respond more slowly to water stress (Vicente-Serrano et al. 2013). Spatial and temporal patterns of vegetation productivity are affected by variability in weather and climate (Bradford et al. 2006). Additional examples of weather and climate impacts on vegetation can be found in, for example, Tilman and Downing (1994), Ji and Peters (2003), Schwinning and Sala (2004), Breshears et al. (2005), Knapp et al. (2008), Malhi et al. (2008), Phillips et al. (2009, 2010), and Saatchi et al. (2013).

Land-atmosphere feedbacks enhance the importance of drought impacts on vegetation. Climate-forced changes in vegetation produce feedbacks to the atmospheric system because of modifications in biogeophysical properties. When vegetation is water stressed, albedo increases and latent energy flux decreases, which may decrease atmospheric instability, convection, and cloud development. Human-forced LULC changes further complicate these land-atmosphere interactions (Pielke 2001; Pielke et al. 2011; Mahmood et al. 2014). Studies have shown that human-forced change in LULC modified regional long-term temperature, precipitation, humidity, and in some cases, atmospheric circulation (Foley et al. 2005; Wang et al. 2009; DeAngelis et al. 2010; de Noblet-Ducoudré et al. 2012; Brovkin et al. 2013; Kumagai et al. 2013; Mahmood et al. 2014; Lawrence and Vandecar 2015).

In this study, we capitalized on prior efforts to monitor vegetation health across the conterminous United States using a hybrid satellite-based measure, known as the vegetation drought response index (VegDRI), that incorporates climate and land-cover data to improve the geospatial representation of moisture impacts on vegetation (Brown et al. 2008; Tadesse et al. 2015). VegDRI is produced by fitting statistical models to satellite vegetation index differences from typical seasonal values, climate-based standardized drought index data, and biophysical environmental parameters. VegDRI was developed to address the need for a monitoring and mapping tool that could provide spatially detailed drought patterns at the national scale and provide local-scale information on the vegetation impacts of drought to support planning, mitigation, and response activities. National-scale comparisons are possible since it uses an objective and repeatable procedure. The index has been used in studies of the impacts of recent droughts in 2011 and 2012 (Tadesse et al. 2015; Otkin et al. 2016).

The overarching goal for this paper is to characterize how vegetation within land-cover types (e.g., grasslands, shrublands, and croplands) in the NCA3 Great Plains region has been affected by weather and climate variations during a recent $24-y r$ period. We primarily focused on grasslands, croplands, and shrublands because they cover the largest areas in the Great Plains region. Together, they 
Earth Interactions - Volume 22 (2018) • Paper No. 17 • Page 4

represent end points in land management intensity, with management most intense in cropland and less intense in shrublands and grasslands.

In this context, specifically, we are focused on the following questions:

- Which land-cover types show the most response of vegetation condition to climate-related extremes within the Great Plains region and the ecoregions therein?

- Which ecoregions in the Great Plains have the most persistent and frequent departures from normal vegetation conditions (positive or negative)?

- What are the spatial and temporal patterns of vegetation condition in the NCA3 Great Plains region, and how do the patterns vary by ecoregion and land-cover class?

The following sections discuss the study area, sources of the data, and methods; present and assess results; and conclude with summary remarks.

\section{Study area}

This study focuses on the Great Plains in the central United States. The Great Plains were selected as the study area due to the large variability in weather conditions, both at a specific location and across the region. Over the study period, droughts in the Great Plains typically covered larger areas and tended to have greater overall impacts than other weather events such as floods, freezes, and hail. Drought events affect large areas (Sheffield et al. 2009), and the dominantly agricultural economic foundation of the Great Plains region is vulnerable to drought impacts (Raz-Yaseef et al. 2015; Tadesse et al. 2015; Otkin et al. 2016).

In this study, we use the NCA3 Great Plains region boundary and a set of ecoregions defined by Omernik (1987) to investigate both the overall relationship and subregional relationships between drought and land cover (Figure 1). The specific geographic boundaries of the Great Plains vary depending on the criteria used (Rossum and Lavin 2000). The NCA3 (Melillo et al. 2014) used administrative boundaries based on a set of contiguous states to define the Great Plains. Ecoregion definitions from Bailey (1989) or Omernik (1987) define the Great Plains and its subregional diversity using the convergence of geophysical and biophysical factors (e.g., geology, soils, topography, climate, and potential natural vegetation).

\subsection{NCA3 Great Plains region}

The NCA3 region is based on state boundaries because many water and land-use decisions are made at the state government level. The area covered by the eight NCA3 states is similar to other definitions of the Great Plains, although eastern parts of Colorado and New Mexico are excluded. The NCA3 Great Plains region's diverse climate is influenced both by its large latitudinal extent from north to south and its east to west range in elevation. Two climate gradients dominate the region. First, average annual precipitation generally decreases from east to west, with greater than $1300 \mathrm{~mm}$ in the eastern part of Oklahoma and Texas and less than $500 \mathrm{~mm}$ in western Texas and the plains of Wyoming and Montana (Shafer et al. 


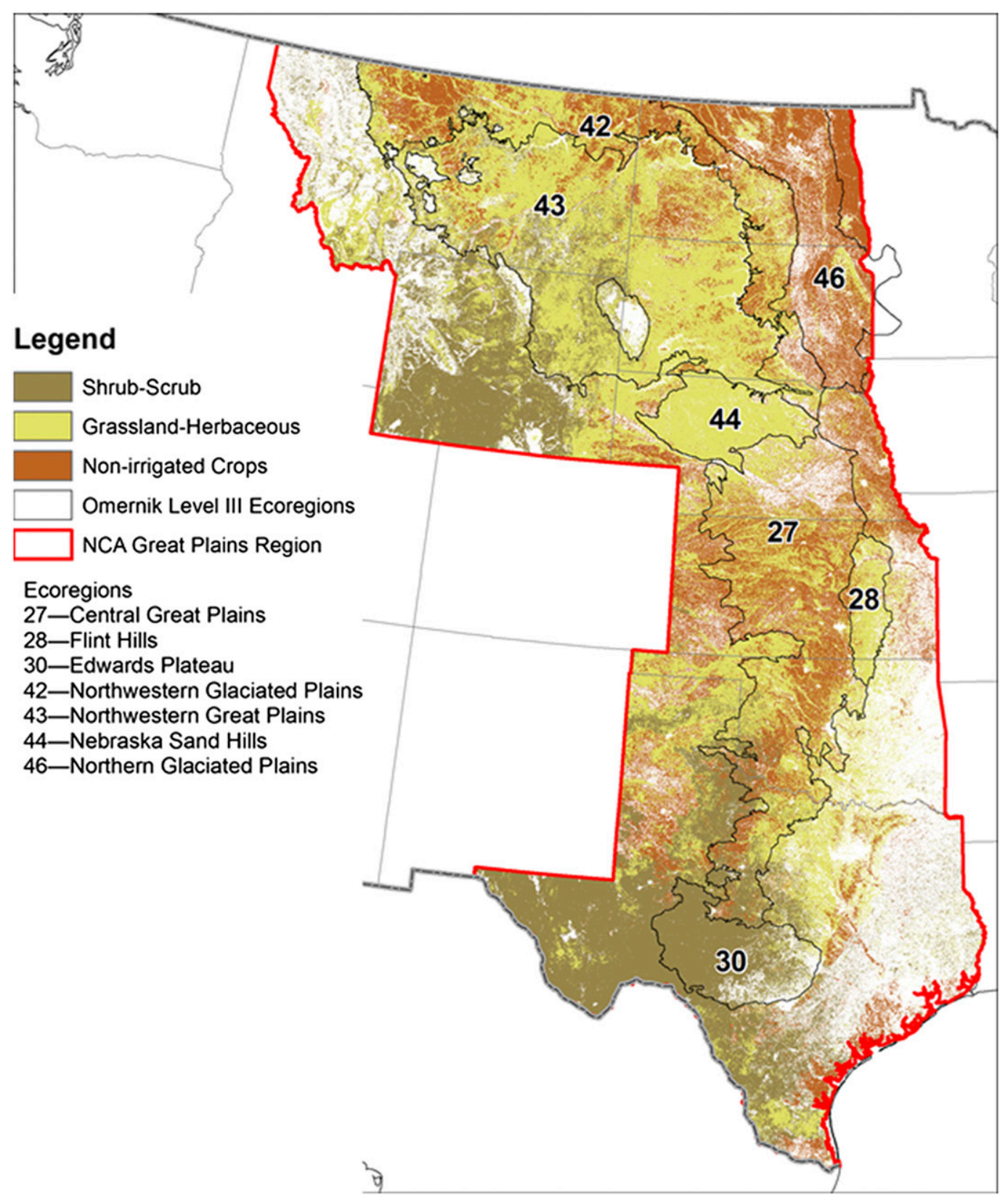

Figure 1. Great Plains study area, showing the Great Plains NCA3 region, seven Omernik level-III ecoregions, and three land-cover classes extracted from the 2006 NLCD.

2014). Second, average temperature decreases from south to north. Land-use practices across the region depend on local topography, soils, and climate. Cultivation predominately occurs in the eastern half of the Great Plains, where there are favorable climate and soil conditions, while the western half is dominated by ranching and grazing (Drummond et al. 2012). Because the region is affected by 
Earth Interactions - Volume 22 (2018) • Paper No. 17 • Page 6

many weather and climate hazards (including drought as one of the most pervasive and widespread), the land uses and land management practices of the Great Plains continually evolve and adapt to periodic droughts (Lauenroth et al. 1999; Andreadis and Lettenmaier 2006; Bradford et al. 2006; Drummond et al. 2012; Livneh and Hoerling 2016). Technology and other management tools aid in adapting land-use practices within this vulnerable region, although the resilience of fragile grassland and shrub ecosystems to continuing climate-related challenges is an ongoing concern.

\subsection{Great Plains ecoregions}

Because the NCA3 regions are based on political (i.e., multiple state) boundaries, we selected a set of ecoregions that represent much of the land cover and climate variability of the NCA3 region. Statistics on the variability and extremes in climate and climate impacts that are calculated for subregional areas will be generalized or dampened when calculated for the NCA3 Great Plains region as a whole. The U.S. Environmental Protection Agency (EPA) level-III ecoregions (Omernik 1987) (Figure 1) provide a useful spatial structure that is based on unifying characteristics of land use, climate, topography, soils, and so on. The ecoregions framework is a basis for comparing and contrasting historical frequency and severity of drought within the larger NCA3 region.

Seven Level III ecoregions that lay within (or mainly within) the larger NCA3 Great Plains region were selected for analysis. These were the Central Great Plains (27), the Nebraska Sand Hills (44), the Northwestern Great Plains (43), the Northern Glaciated Plains (46), the Northwestern Glaciated Plains (42), the Flint Hills (28), and the Edwards Plateau (30). Descriptions of the individual ecoregions follow.

\subsubsection{Central Great Plains (ecoregion 27)}

The Central Great Plains ecoregion is a large, elongated area stretching from central Nebraska through Kansas and Oklahoma into north-central Texas (Drummond et al. 2012; Drummond 2015). The dominant land uses are agricultural due to relatively level topography, water availability, fertile soils, and a long growing season. Approximately one-half of the ecoregion is occupied by cropland. Wheat is common, and much of the hard winter-wheat area of Kansas and Oklahoma is in the Central Great Plains. The northern part of the ecoregion along the Platte River in Nebraska includes extensive irrigated cropland. The other dominant land uses are associated with livestock grazing and confined animal-feeding operations. The ecoregion experiences warm summer temperatures, and average annual precipitation levels range from about $500 \mathrm{~mm} \mathrm{yr}^{-1}$ in the western part of the ecoregion to $800 \mathrm{~mm} \mathrm{yr}^{-1}$ in the east.

\subsubsection{Nebraska Sand Hills (ecoregion 44)}

The Nebraska Sand Hills ecoregion is almost entirely within the state of Nebraska. The Sand Hills include one of the largest extents of grasslands in the United States, and the region of grass-stabilized sand dunes is considered to be one 
Earth Interactions - Volume 22 (2018) • Paper No. 17 • Page 7

of the most distinct and homogeneous ecoregions in North America (Omernik 1987; Taylor 2015b). Topography is irregular and varies locally by as much as $60 \mathrm{~m}$. The climate is considered to be semiarid, with most precipitation falling during May and June. Annual average precipitation ranges from $380 \mathrm{~mm}$ in the west to $635 \mathrm{~mm}$ in the east (HPRCC 2018). Soils in the Nebraska Sand Hills ecoregion are sandy and characterized by low water-holding capacity. Because of this, agricultural land uses (chiefly, livestock grazing and hay production) are at high risk during periods of drought (Wilhelmi and Wilhite 2002). Wetlands and wet meadows are found in the margins of lakes and spring-fed streams.

\subsubsection{Northwestern Great Plains (ecoregion 43)}

The Northwestern Great Plains ecoregion is a large ecoregion that covers eastern Montana, northeastern Wyoming, western North Dakota, western South Dakota, and northern Nebraska (Sayler 2015). The ecoregion is a semiarid rolling plain of shale- and sandstone-derived soils, punctuated by buttes and badlands. This mostly unglaciated plain consists of shallow soils with clayey textures that are not conducive to growing crops but are suitable for grazing. The climatic conditions include erratic annual precipitation amounts of $250-510 \mathrm{~mm}$, with most falling during the summer months. Semiarid grasslands cover most of the ecoregion. The most common land use is livestock grazing. Crop agriculture is limited by soil quality, precipitation levels, and limited access to water for irrigation. For cropped areas, spring wheat is dominant, but genetically modified crops such as corn are becoming increasingly common in the eastern part of the ecoregion.

\subsubsection{Northern Glaciated Plains (ecoregion 46)}

The Northern Glaciated Plains ecoregion runs north-south across eastern North Dakota and South Dakota and part of western Minnesota (Omernik 1987; Auch 2015). The climate of the Northern Glaciated Plains ecoregion is considered to be continental (hot or warm summers and cold winters). Average annual precipitation increases from northwest to southeast and ranges between 380 and $760 \mathrm{~mm}$ (HPRCC 2018). Continental glaciation has left many glacial landforms that contribute to the types and variability of land uses and covers seen today. Agricultural land, grasslands, wetlands, and water make up the general mosaic of land cover in the ecoregion. Agriculture is the most common land-cover class in the ecoregion, and grain and cattle production are the dominant land uses.

\subsubsection{Northwestern Glaciated Plains (ecoregion 42)}

The Northwestern Glaciated Plains ecoregion stretches from the Rocky Mountains across northern Montana, through northwestern and central North Dakota and central South Dakota, and into northern Nebraska (Taylor 2015a). Gravelly outwash material from continental glaciers marks the western and southwestern borders of the ecoregion. Groundwater is shallow and plentiful, and the area is dotted with numerous semipermanent and seasonal wetlands, locally referred to as "prairie potholes." The ecoregion has a semiarid climate characterized by cold winters, hot summers, low humidity, light rainfall, and plentiful sunshine. Annual average precipitation ranges between $250 \mathrm{~mm}$ in the northwest and $760 \mathrm{~mm}$ in the 
Earth Interactions - Volume 22 (2018) • Paper No. 17 • Page 8

southeast (HPRCC 2018). Land uses such as dryland farming and grazing have been shaped by the semiarid climate and strong, drying winds. In the west, rangeland and wheat fields are widespread, with agriculture on the undissected gravel benches and in the alluvial river valleys. Farther east, extensive grain farms of wheat, soybeans, sunflowers, and corn are common, as are hay and oilseed crops.

\subsubsection{Flint Hills (ecoregion 28)}

The Flint Hills ecoregion includes the Flint Hills in eastern Kansas and the Osage Hills in north-central Oklahoma (Kambly 2015). A subhumid continental climate accounts for large daily and seasonal temperature fluctuations in the Flint Hills ecoregion. The ecoregion receives about $760-960 \mathrm{~mm}$ of annual precipitation, with most falling during the growing season, from April to September. The dominant land use is livestock grazing, and the leading land-cover types are grasslands, dominated by warm-season grasses, and shrublands. The Flint Hills ecoregion includes the largest remnant of tallgrass prairie in North America.

\subsubsection{Edwards Plateau (ecoregion 30)}

The Edwards Plateau ecoregion in Texas is an uplifted and eroded limestone plateau that is characterized by hilly topography with elevations ranging from 100 to more than $1000 \mathrm{~m}$ (Stier and Friesen 2015). The ecoregion is semiarid, and average annual rainfall varies from $380 \mathrm{~mm}$ in the west to $840 \mathrm{~mm}$ in the east. Peak rainfall is typically from May through September. Land cover is mainly rangeland and is composed of small trees, shrubs, and grasses. The major land use is livestock grazing. Although historically it has been sparsely populated, human settlement in this rugged ecoregion is expanding.

\section{Land-cover data and methods}

A basic land-cover scheme was employed in the study to characterize the influence of climate on land cover. The 2006-era National Land Cover Database (NLCD; Fry et al. 2011) was summarized at a 1-km resolution. The categories of shrubland, grassland, and cultivated crops were the most prevalent in the Great Plains and were the major land-cover focus of the study. Irrigated croplands are excluded from this study on the basis of the assumption that water would be available to the crops even during drought periods.

\subsection{Irrigation data}

Large parts of the Great Plains are irrigated, with crops receiving supplemental water to improve yields and offset drought impacts (Gollehon and Quinby 2000; Brown and Pervez 2014). In irrigated croplands, the relationship between vegetation condition and climate was complicated by the application of water from alternate sources (e.g., groundwater). For this reason, irrigated agriculture was outside the scope of this study. In practice, irrigated locations would likely show less influence from drought because of the application of water to improve crop productivity. The influence of irrigation on the study was minimized by masking 
Earth Interactions • Volume 22 (2018) • Paper No. 17 • Page 9

those areas from analysis. A 2007-era irrigation map was created with the methods of Pervez and Brown (2010), who developed a 1-km map indicating the percent of the grid cell that was irrigated. Any grid cell containing greater than $49 \%$ irrigation was eliminated from further drought analysis.

\subsection{Vegetation condition drought index data}

VegDRI is an indicator of vegetation condition that is constructed from multiple climate and satellite inputs (Brown et al. 2008; Tadesse et al. 2015; USGS 2015). VegDRI uses satellite data that directly assess vegetation condition (as described below), meteorological station data in the form of the self-calibrated Palmer drought severity index (PDSI) and the standardized precipitation index, land cover, soil available water capacity, irrigated agriculture, and ecoregions. The PDSI (Palmer 1965; Wells et al. 2004) uses meteorological station data to calculate a supply-and-demand model for water balance including precipitation, temperature, and available water-holding capacity of soils, and it does not assess vegetation condition. Hence, the PDSI does not measure vegetation response to drought and is not suitable for this study. See Heim (2002) for a more thorough review of many types of drought indices.

In addition, VegDRI was selected for this study because usage of satellite data means that it is spatially representative (as opposed to a drought index based solely on unevenly distributed weather station data), it is produced with an automated and repeatable procedure so that it can be compared between regions, and it is easily available. The index responds to variations in both weather (e.g., local rainfall) and climate (e.g., long-term rainfall averages), as well as variations in vegetation vigor as estimated by time series satellite data of the normalized difference vegetation index (NDVI). Satellite NDVI is input to VegDRI models as an anomaly indicator where NDVI is accumulated on a 2-week time step in the growing season (a proxy measure for net primary productivity) and then is compared with a long-term average accumulated NDVI (from the period 1989-2008). VegDRI has been implemented in a near-real-time fashion and has been in operational production on a weekly basis since 2009. Satellite input NDVI was provided by the Advanced Very High Resolution Radiometer (AVHRR) instrument and the U.S. Geological Survey (USGS) Greenness mapping program (Eidenshink 2006).

The historical VegDRI biweekly time series from 1989 to 2012 was stratified by ecoregion, land-cover type, and irrigation status and summarized by creating histograms of drought classes from the original VegDRI within each stratum. The stratification datasets were reprojected and resampled to correspond with the VegDRI data. VegDRI and the stratification datasets were overlaid, and a histogram of the drought status within each ecoregion and land-cover group was computed for each biweekly period. For each pixel, an average across all years was used to determine when the pixel was typically "in season," with active vegetation growth. Areas that were not in season were excluded from the VegDRI data, and therefore the land area within a biweekly image changed during the season in a pattern that repeated each year. This is done so that pixels with early- and late-season droughts are not excluded from the analysis. Fractional and percentage results describe fractions of both space and time, since we are interested in summarizing across area but also throughout the study area. 
Earth Interactions - Volume 22 (2018) • Paper No. 17 • Page 10

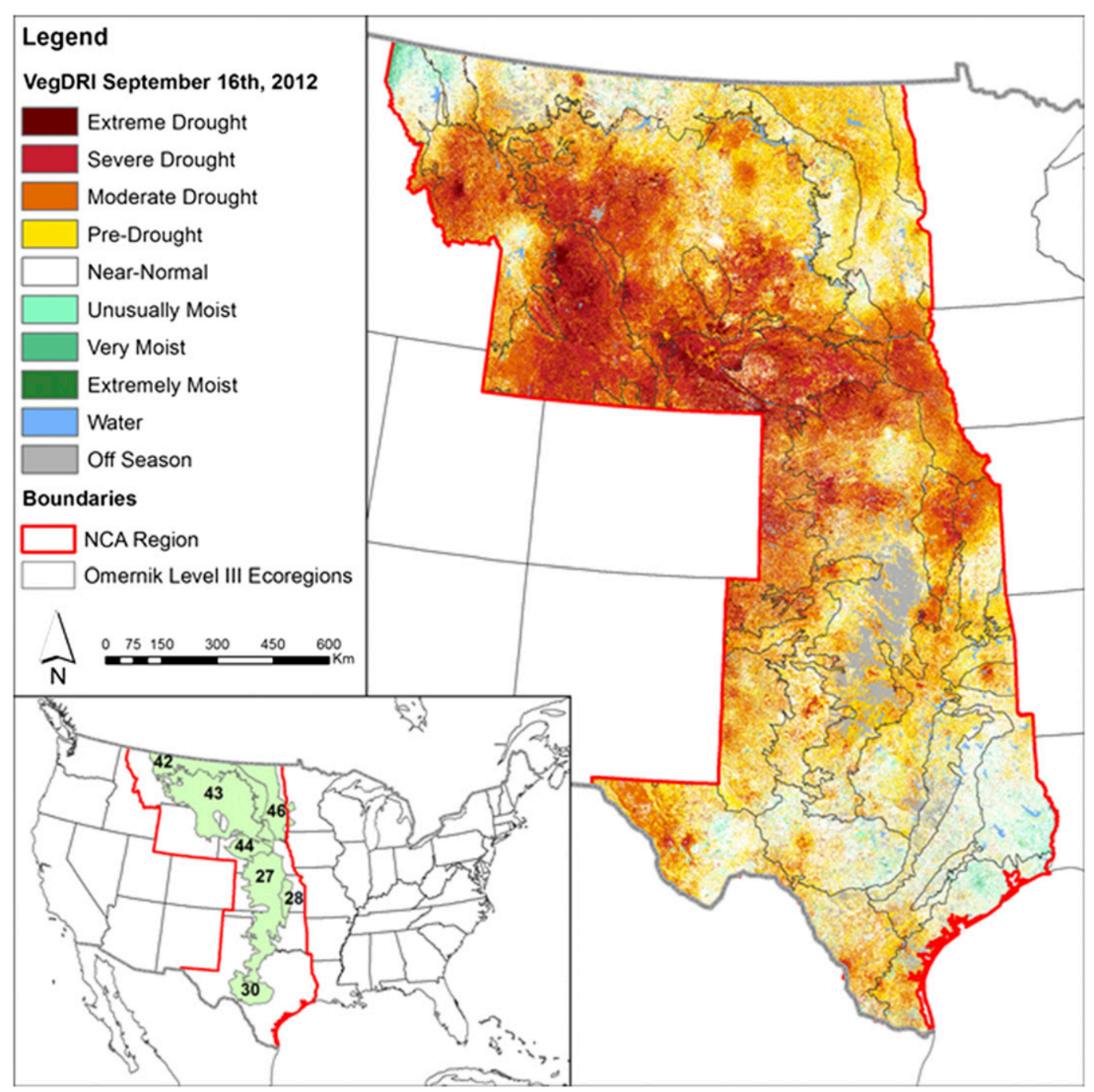

Figure 2. The map of VegDRI for September 2012, provided here as an example to demonstrate the spatial detail of this drought map across the Great Plains region.

The VegDRI data were initially summarized using nine classes on the basis of the PDSI, ranging from "extreme drought" to "extreme moist spell" (Figure 2). The three dry classes are further simplified as "drought," the three middle as "normal," and the three wet classes as "moist." To calculate fractional drought coverage across time, the total number of pixels in each class was divided by the total number of in-season pixels to get a percentage. Average values of drought index within an ecoregion were calculated from the nine drought classes; the number of pixels in each class was multiplied by an integer (extreme drought by -4 , severe drought by -3 , and so on through extremely moist by 4 ), summed, and then divided by the total number of in-season pixels. This method was used instead of averaging the original values of drought index for calculation efficiency and 
Earth Interactions - Volume 22 (2018) • Paper No. 17 • Page 11

might lead to a slight difference in average index values. A drought event was considered to occur if the accumulated area of moderate, severe, and extreme drought was $25 \%$ or greater.

To assess the degree to which individual ecoregions behaved in the same way as the NCA3 Great Plains as a whole, VegDRI values were compared across the study area for all time steps in the study period. First, drought index values were calculated at each biweekly time step for every ecoregion and for the NCA3 Great Plains region. If an ecoregion had fewer than 100 in-season pixels for a time step, that case was excluded. Then, the average difference between the NCA3 Great Plains and an ecoregion was computed as

$$
\frac{1}{N} \sum_{t=1}^{N}\left|y_{t}-x_{t}\right|
$$

where $y_{t}$ is the drought index for NCA3 Great Plains, $x_{t}$ is the drought index for the ecoregion to be compared, $t$ is the time index, and $N$ is the number of valid biweekly observations. The more closely correlated an ecoregion was to the NCA3 Great Plains, the smaller was the average difference. Differences between ecoregions were computed in the same way. Analysis was performed in ArcGIS (ESRI Co.) and IDL (Harris Geospatial Solutions, Inc.).

\section{Results}

Drought conditions as measured by VegDRI vary notably through time, with the fraction of the Great Plains (NCA3 region 6) in moderate, severe, or extreme drought (during the growing season) ranging from 1.5\% (July 1993) to 54\% (September 2012). Drought coverage through time is shown in Figure 3, with colors in each bar representing the fraction of the in-season area in each of the nine drought categories (e.g., dark green $=$ extreme wet, yellow $=$ normal, and red $=$ extreme drought) for that biweekly VegDRI observation. Pixels classified as off season are masked (white background in the Figure 3 histograms). Note that drought affected large areas of the Great Plains in 1989, 2002, and 2012. See Table 1 for the total in-season area for each NLCD class and ecoregion, as represented by the maximum height of the histograms in Figures 4-7.

Individually, the Great Plains ecoregions show slightly different drought frequencies and severity from the entire NCA3 Great Plains region. Three examples [Northern Glaciated Plains (46), Northwestern Great Plains (43), and Central Great Plains (27)] are shown (Figures 4-6; other ecoregions plots can be found in Figures S1-S4 of the online supplemental material). These examples are large ecoregions that cover much of the Great Plains and have substantial representation of each studied land-cover type, with the exception of shrub/scrub, which was not found in the Northern Glaciated Plains.

Drought fraction varies spatially as well as temporally, with VegDRI measuring more frequent drought in some ecoregions and land-cover types (Table 1). Averaged over time for 1989-2012 and by ecoregion and land-cover type, the overall VegDRI drought fraction for grassland, shrub/scrub, and nonirrigated cultivated crops was generally less than $20 \%$, with only one exception [grassland in the Northwestern Great Plains (43)]. Cropland had a lower drought fraction 


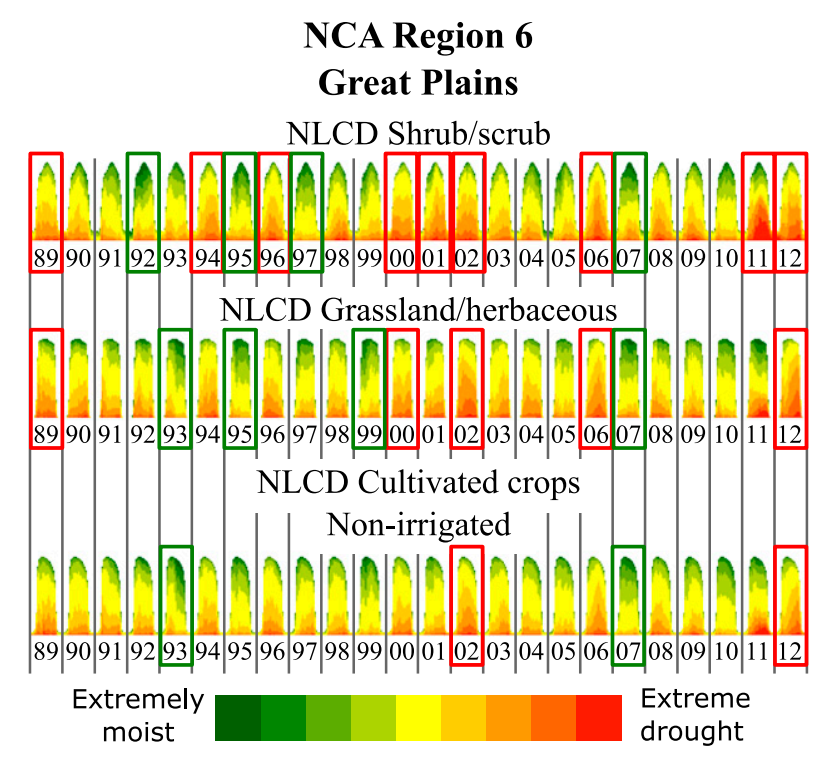

Figure 3. Temporal histograms showing the area of each major land-cover type (scrub/shrub, grassland, and cropland) within the entire Great Plains (NCA3 region 6) in moist and dry VegDRI categories. Date is shown on the $x$ axis, with one point for every biweekly observation. The $y$ axis is the proportion of the maximum number of in-season pixels in each of nine drought categories, where white space represents pixels that are not in season. Red boxes mark years for which the accumulated area of moderate, severe, and extreme drought was $25 \%$ or greater. Green boxes mark years for which the accumulated area of unusually, very, and extremely moist was $25 \%$ or greater.

(10\%-13\% for ecoregions with more than $2000 \mathrm{~km}^{2}$ of crops). Wet conditions occurred less frequently than dry conditions (excluding small areas, wet conditions were $\leq 15 \%$ in grasslands and croplands). Normal conditions were present during $\sim 70 \%$ of the study period. Results for grassland in Edwards Plateau (30), scrub/ shrub in Northwestern Glaciated Plains (42), and nonirrigated crops in Nebraska Sand Hills (44), Flint Hills (28), and especially Edwards Plateau (30) should be treated with caution, as these cases are represented by relatively small areas.

Of particular note is an east-west gradient of increasing drought occurrence across the northern Great Plains, from Northern Glaciated Plains (46) to Northwestern Glaciated Plains (42) to Northwestern Great Plains (43) (Figure 7). The Northern Glaciated Plains (46) exhibited the lowest percentage of drought over the study period in nonirrigated cultivated crops and grassland land cover. Drought occurred only in three years in grassland/herbaceous land cover $(1992,2002$, and 2012), whereas six years were relatively wet (Figure 4). Only one seasonal drought, in 2012, affected greater than $25 \%$ of the area of nonirrigated cultivated crops. In contrast, the Northwestern Great Plains (43) had the highest frequency of drought events. In grassland/herbaceous land cover, 10 of the 24 years $(1989,1990,1992$, 1994, 2000, 2001, 2002, 2004, 2006, and 2012) had substantial drought (Figure 5). The east-west pattern is less clear during wet periods; there are 2 times as many 
Earth Interactions V Volume 22 (2018) • Paper No. 17 • Page 13

Table 1. Land-cover area, percentage of area, and percentage in drought, normal, and wet conditions (1989-2012) for the Great Plains ecoregions.

\begin{tabular}{|c|c|c|c|c|c|}
\hline \multirow[b]{2}{*}{$\begin{array}{c}\text { Ecoregion } \\
\text { No. }\end{array}$} & \multirow[b]{2}{*}{ Ecoregion name } & \multirow[b]{2}{*}{ Description } & \multicolumn{3}{|c|}{ Land cover } \\
\hline & & & Grassland & $\begin{array}{c}\text { Shrub/ } \\
\text { scrub }\end{array}$ & $\begin{array}{l}\text { Nonirrigated } \\
\text { cultivated crops }\end{array}$ \\
\hline \multirow[t]{5}{*}{6} & NCA3 Great Plains & Area $\left(\mathrm{km}^{2}\right)$ & 795940 & 481762 & 469368 \\
\hline & & Percent of ecoregion area & $34 \%$ & $21 \%$ & $20 \%$ \\
\hline & & Total percent drought & $19 \%$ & $20 \%$ & $13 \%$ \\
\hline & & Total percent normal & $69 \%$ & $67 \%$ & $75 \%$ \\
\hline & & Total percent wet & $12 \%$ & $13 \%$ & $12 \%$ \\
\hline \multirow[t]{5}{*}{46} & Northern Glaciated & Area $\left(\mathrm{km}^{2}\right)$ & 13504 & - & 91432 \\
\hline & Plains & Percent of ecoregion area & $10 \%$ & - & $68 \%$ \\
\hline & & Total percent drought & $11 \%$ & - & $10 \%$ \\
\hline & & Total percent normal & $76 \%$ & - & $79 \%$ \\
\hline & & Total percent wet & $13 \%$ & - & $11 \%$ \\
\hline \multirow[t]{5}{*}{42} & Northwestern & Area $\left(\mathrm{km}^{2}\right)$ & 89162 & 2378 & 69659 \\
\hline & Glaciated Plains & Percent of ecoregion area & $51 \%$ & $1 \%$ & $40 \%$ \\
\hline & & Total percent drought & $17 \%$ & $17 \%$ & $11 \%$ \\
\hline & & Total percent normal & $72 \%$ & $74 \%$ & $77 \%$ \\
\hline & & Total percent wet & $11 \%$ & $10 \%$ & $12 \%$ \\
\hline \multirow[t]{5}{*}{43} & Northwestern & Area $\left(\mathrm{km}^{2}\right)$ & 254892 & 39212 & 38941 \\
\hline & Great Plains & Percent of ecoregion area & $71 \%$ & $11 \%$ & $11 \%$ \\
\hline & & Total percent drought & $21 \%$ & $20 \%$ & $13 \%$ \\
\hline & & Total percent normal & $68 \%$ & $70 \%$ & $76 \%$ \\
\hline & & Total percent wet & $11 \%$ & $10 \%$ & $11 \%$ \\
\hline \multirow[t]{5}{*}{44} & Nebraska Sand Hills & Area $\left(\mathrm{km}^{2}\right)$ & 54834 & - & 1085 \\
\hline & & Percent of ecoregion area & $93 \%$ & - & $2 \%$ \\
\hline & & Total percent drought & $17 \%$ & - & $19 \%$ \\
\hline & & Total percent normal & $70 \%$ & - & $66 \%$ \\
\hline & & Total percent wet & $12 \%$ & - & $15 \%$ \\
\hline \multirow[t]{5}{*}{27} & Central Great Plains & Area $\left(\mathrm{km}^{2}\right)$ & 111683 & 23571 & 109355 \\
\hline & & Percent of ecoregion area & $41 \%$ & $9 \%$ & $40 \%$ \\
\hline & & Total percent drought & $17 \%$ & $11 \%$ & $13 \%$ \\
\hline & & Total percent normal & $72 \%$ & $71 \%$ & $73 \%$ \\
\hline & & Total percent wet & $12 \%$ & $18 \%$ & $14 \%$ \\
\hline \multirow[t]{5}{*}{28} & Flint Hills & Area $\left(\mathrm{km}^{2}\right)$ & 21202 & - & 3628 \\
\hline & & Percent of ecoregion area & $76 \%$ & - & $13 \%$ \\
\hline & & Total percent drought & $15 \%$ & - & $13 \%$ \\
\hline & & Total percent normal & $71 \%$ & - & $75 \%$ \\
\hline & & Total percent wet & $15 \%$ & - & $11 \%$ \\
\hline \multirow[t]{5}{*}{30} & Edwards Plateau & Area $\left(\mathrm{km}^{2}\right)$ & 2041 & 60835 & 131 \\
\hline & & Percent of ecoregion area & $3 \%$ & $81 \%$ & $0 \%$ \\
\hline & & Total percent drought & $18 \%$ & $18 \%$ & $14 \%$ \\
\hline & & Total percent normal & $67 \%$ & $66 \%$ & $70 \%$ \\
\hline & & Total percent wet & $15 \%$ & $16 \%$ & $16 \%$ \\
\hline
\end{tabular}

wet years in grassland in the Northern Glaciated Plains (46) (six) as in the Northwestern Great Plains (43) (three), but both have a similar percentage of wet area in cultivated cropland $(11 \%)$.

Relative to natural land-cover types (grassland and shrub/scrub), drought years were generally less frequent in nonirrigated cropland; Nebraska Sand Hills (44) is the exception, but it has a very low area of nonirrigated crops. For the entire NCA3 region, drought measured by VegDRI was more frequent for scrub/shrub ( 9 years) 


\section{Ecoregion 46 \\ Northern Glaciated Plains}

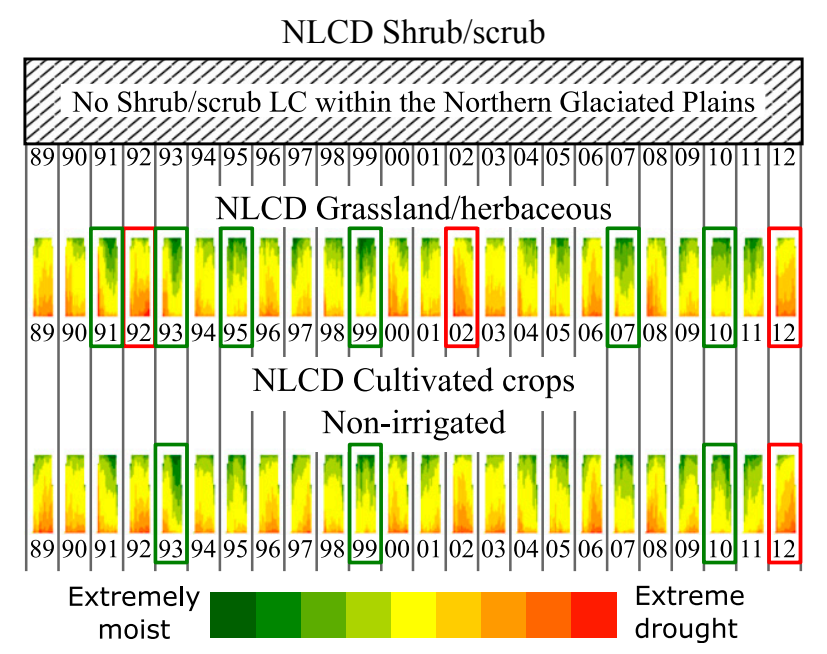

Figure 4. As in Figure 3, but within the Northern Glaciated Plains (ecoregion 46).

than grassland/herbaceous land cover (5 years) or nonirrigated cultivated crops ( 2 years) during the 24-yr period of the study. The only two years that exceeded the drought threshold in cultivated crops (2002 and 2012) were noteworthy for billions of dollars of agricultural impacts (NOAA NCEI 2017). Wet and dry conditions occurred with roughly similar frequencies in cropland, but there was an imbalance

\section{Ecoregion 43 \\ Northwestern Great Plains}

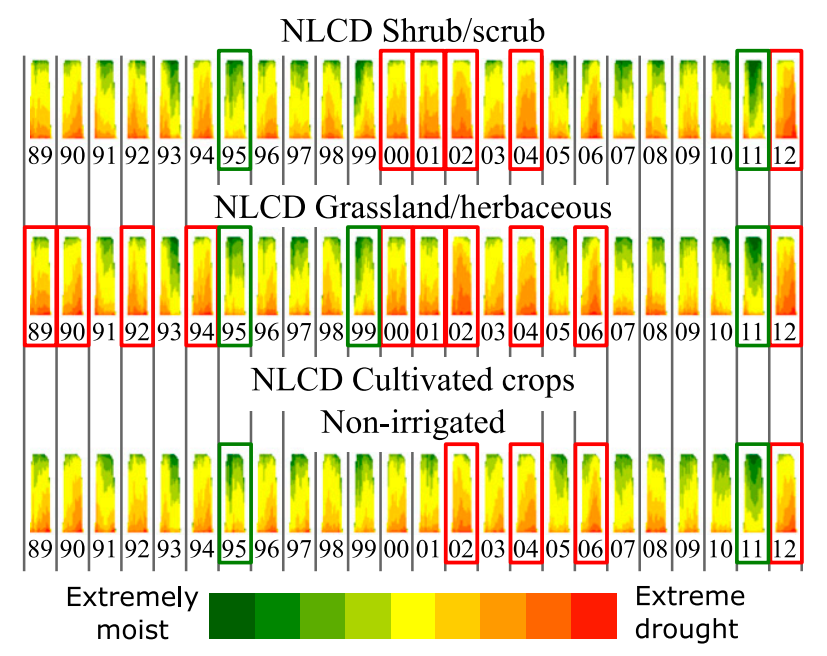

Figure 5. As in Figure 3, but within the Northwestern Great Plains (ecoregion 43). 


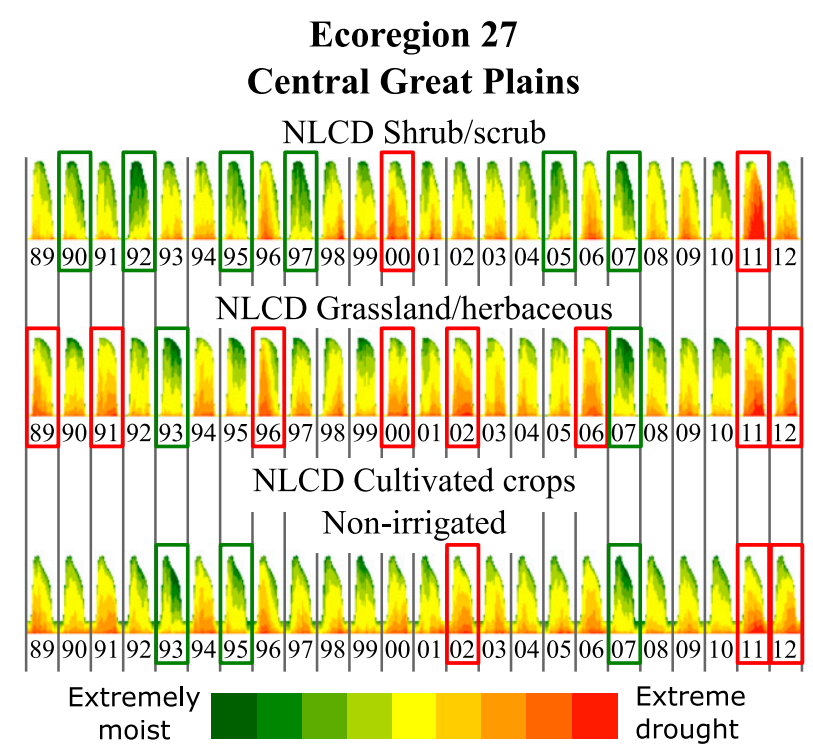

Figure 6. As in Figure 3, but within the Central Great Plains (ecoregion 27).

between wet and dry in grassland, most noticeably in Northwestern Great Plains (43), where there were 3 times as many dry years as wet years (10 vs 3 ) and almost double the fractional coverage of dry over wet conditions (21\% vs $11 \%)$. Wet years were slightly more common in grassland than cropland (for the NCA3 region, four years of wet in grassland vs two years in cropland), but both were broadly similar to the frequency of drought in cropland. To the south, in the Central Great Plains (27), drought was more frequent in grassland/herbaceous land cover and less so in scrub/ shrub and nonirrigated cultivated cropland, with drought frequency of eight, two, and three events during the study period (Figure 6).

In biweekly observations, VegDRI can vary significantly across the Great Plains (e.g., there was more intense drought in Wyoming than in Texas for the date shown in Figure 2). One way to investigate this variation is pairwise comparison of ecoregions through time (Figure 8). In each comparison plot, a large amount of scatter and a high value for the mean difference between the two ecoregions demonstrates that the two ecoregions often have different drought values and are not well correlated. In general, ecoregions that are more distant from each other are less similar in how their drought values behave through time. More specifically, the Northern Glaciated Plains (46), Northwestern Glaciated Plains(42), Northwestern Great Plains (43), and Nebraska Sand Hills (44) group together, with relatively high correlation (low average absolute difference) in all pairwise comparisons. A southern group composed of the Central Great Plains (27), Flint Hills (28), and (to a lesser degree) Edwards Plateau (30) also group together, but there is less correlation (larger average absolute difference) between the northern and southern ecoregions.

Ecoregions within the Great Plains NCA3 region vary in how similar their VegDRI drought behavior was to that of the Great Plains NCA3 region as a whole (Figure 9). Large plains ecoregions with a sizable overall presence of grassland land cover [Northern Glaciated Plains (46), Northwestern Glaciated Plains (42), 


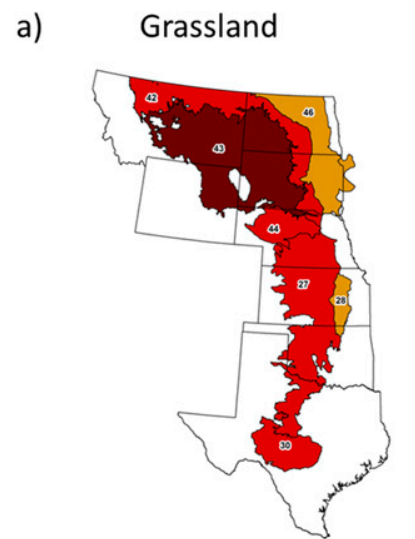

d)

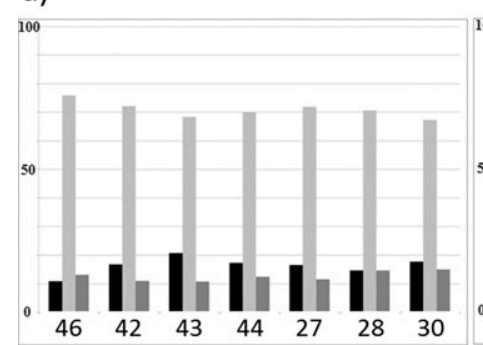

b) Shrub/Scrub

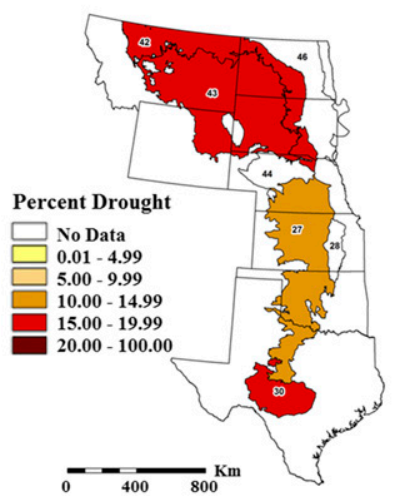

e)

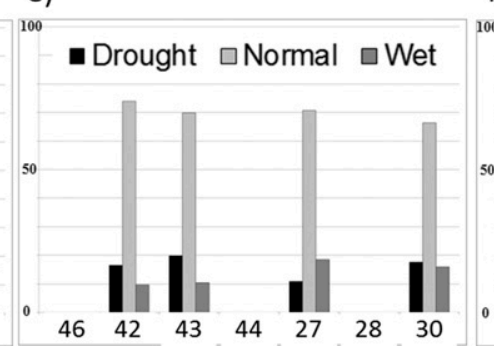

c)Non-irrigated Cropland

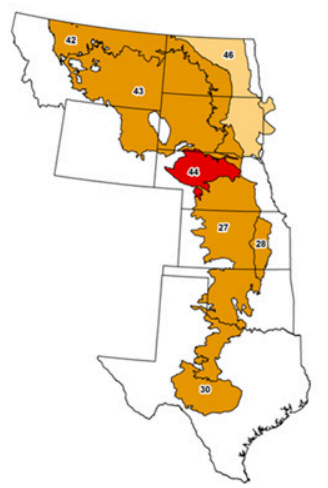

f)

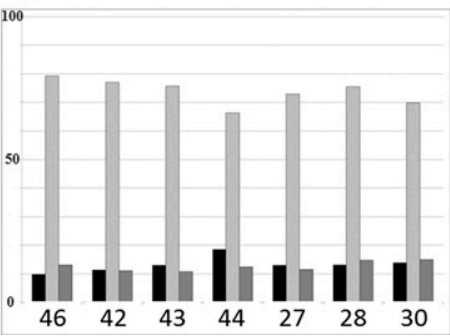

Figure 7. Maps showing the historical percentage of drought affecting specific landcover types: (a) grassland, (b) shrub/scrub, and (c) nonirrigated cultivated crops across the Great Plains for the study period. Also shown are charts of the percentage of drought, normal, and wet conditions for specific landcover types: (d) grassland, (e) shrub/scrub, and (f) nonirrigated cultivated crops.

Northwestern Great Plains (43), and Central Great Plains (27); Table 1] generally had biweekly drought values that were similar to the NCA3 region as a whole. However, mountain ecoregions in western Montana/Wyoming and coastal ecoregions in Texas are not well represented by the NCA3 average, whereas eastern parts of Colorado and New Mexico are excluded from the Great Plains NCA3 region despite having ecoregions that were well correlated.

Although all of the studied ecoregions have drought values that correlate with the NCA3 Great Plains drought average values through time, the smaller ecoregions [Nebraska Sand Hills (44), Flint Hills (28), and Edwards Plateau (30)] were less well correlated, with higher mean differences (last column of Figure 8). The smaller ecoregions also tended to have more extreme drought values than the NCA3 Great Plains average. For example, for the NCA3-Flint Hills comparison, a line fit to the data points would have a steeper slope than the 1:1 line (Figure 8). In comparisons between ecoregions, the smaller ecoregions also usually have more extreme drought values (e.g., in the Central Great Plains-Flint Hills comparison). One potential explanation for this is that local extremes are represented in summary statistics for smaller ecoregions but are dampened when we calculate an average drought index for larger regions. 
Earth Interactions - Volume 22 (2018) - Paper No. 17 • Page 17

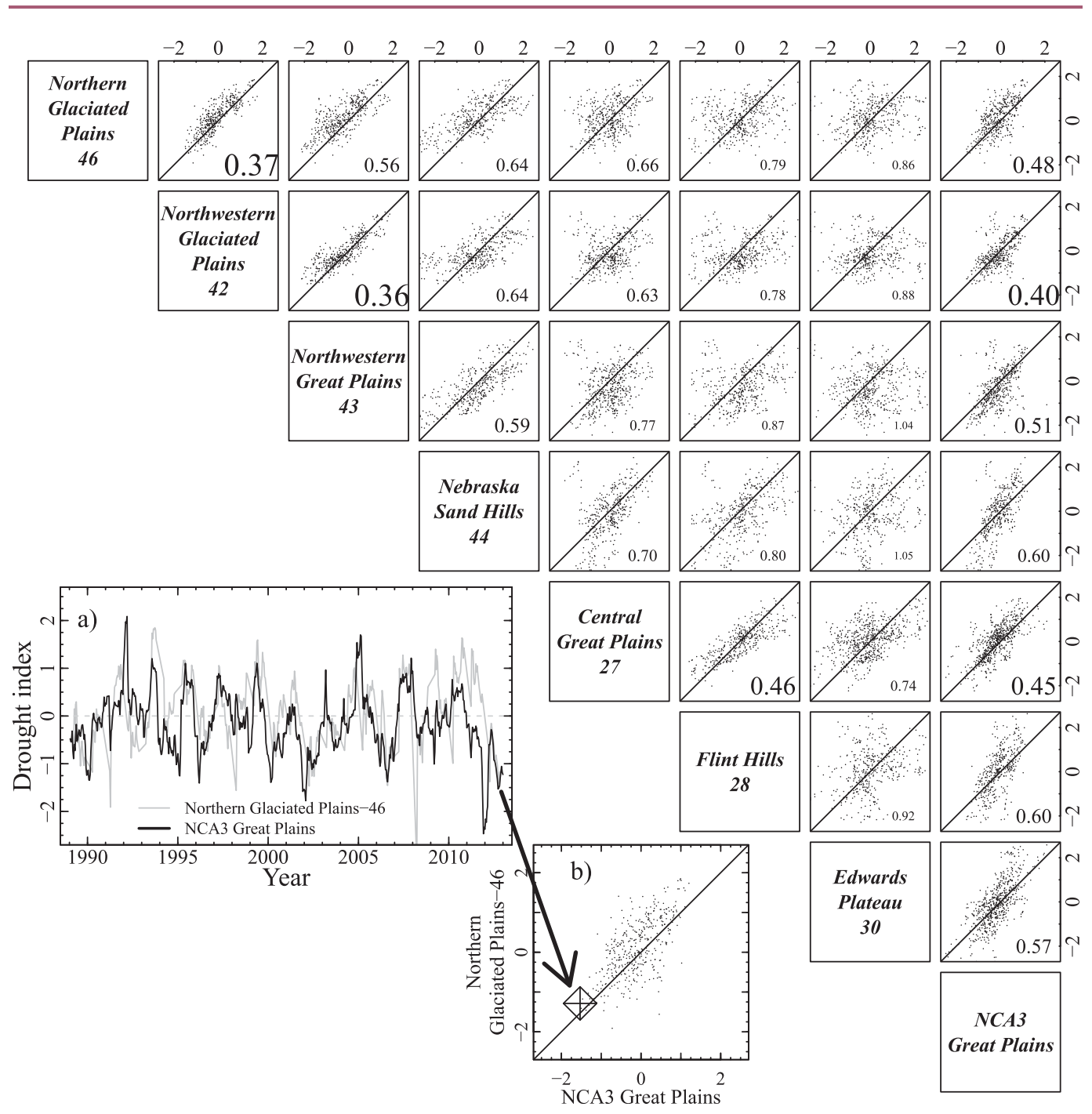

Figure 8. A comparison of VegDRIs between ecoregions. Drought values at (a) each biweekly time step are plotted as a point, with (b) the drought index in one ecoregion as the $x$ value and in the other ecoregion as the $y$ value. Pairwise comparisons of ecoregions are shown in the rest of the figure, with values from one ecoregion (or NCA3 Great Plains) on the $x$ axis and another ecoregion on the $y$ axis ((b) is a copy of the panel in the upper right). The 1:1 line is included in each panel for comparison. Numbers in the bottom right of each panel are the average absolute difference between the two time series.

Land-cover type also affects similarity of drought behavior between ecoregions. For example, the Northwestern Great Plains (43) was similar to the NCA3 Great Plains region within grasslands but was less so in the shrub/scrub land cover. In general, the NCA3 Great Plains average scrub/shrub correlates more with ecoregions in the southern section of the region, whereas NCA3 average grassland and cropland are more similar to northern ecoregions. 


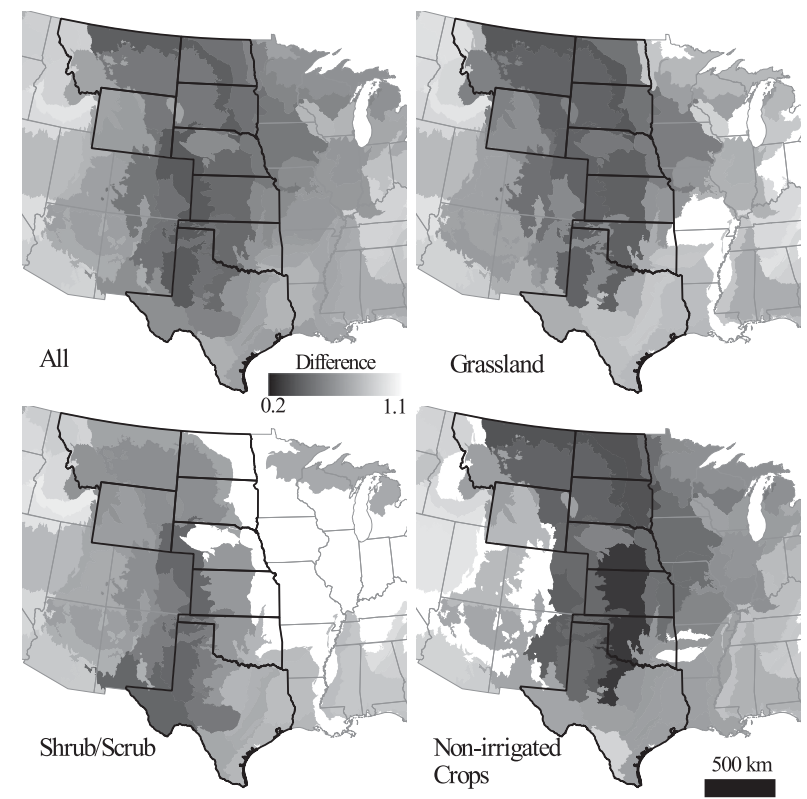

Figure 9. Similarity between NCA3 Great Plains drought index and ecoregion drought index. Darker ecoregions are more similar to the NCA3 Great Plains region (the difference is smaller). Pixels in NLCD land-cover categories: (a) all pixels, (b) grassland, (c) shrub/scrub, and (d) nonirrigated crops. Blank ecoregions do not have sufficient representation of that NLCD class. NCA3 Great Plains states are outlined in black.

\section{Discussion}

The NCA3 regions provide a useful way to summarize climate effects within administrative boundaries, but some new patterns can be observed by investigating the ecologically focused ecoregions. In the NCA3 Great Plains region, areas with ecosystems that are not well represented by the region as a whole are included along the edges (e.g., northwestern Montana includes parts of ecoregions of the Rocky Mountains). When using the NCA3 framework, features of these areas could potentially be neglected because the focus is placed on more central ecoregions that are not split by NCA3 region boundaries. Also, including different kinds of ecoregions in the NCA3 region average is likely to add extra noise to the drought time series, as they will not necessarily react to drought in the same way as the dominant ecoregions. In this study, the NCA3 Great Plains average drought values were similar to those of the major Great Plains ecoregions, except for the northwestern and southeastern ecoregions (Figure 9). The Rockies and the Gulf Coast have different precipitation patterns and more forest than the rest of the NCA3 Great Plains region, and therefore it is not surprising that drought frequency and severity are somewhat different there.

Comparisons of ecoregions within the Great Plains highlight the similarity between nearby ecoregions and spatial autocorrelation. Ecoregions that are in close geographical proximity tend to have correlated droughts, whereas more distant 
Earth Interactions - Volume 22 (2018) • Paper No. 17 • Page 19

ecoregions become increasingly different (Figure 8). The difference between the northern and southern sections of the Great Plains is particularly noteworthy. The large northern ecoregions [Northern Glaciated Plains (46), Northwestern Glaciated Plains (42), and Northwestern Great Plains (43)] are better correlated with each other than with Central Great Plains (27) [or Western High Plains (25) and Southwestern Tablelands (26); not shown]; since the northern ecoregions are all closer to each other than to the southern ecoregions, this is not surprising, but it does support separate consideration of the northern and southern plains.

\section{1. Drivers of differences in drought between LULC types}

Across the Great Plains, drought was detected by VegDRI more frequently in grassland and shrubland land-cover types than in nonirrigated cultivated cropland (Table 1). This result suggests that cropland could be less sensitive to drought than grassland (at least for the drought severity seen during the study period). However, attribution is difficult because there are a number of processes that could contribute to differences in VegDRI drought detection among the land-cover types.

For one, crops are more intensively managed than grassland or shrubland, and managers could be taking actions that reduce the impact of drought on their crops, such as planting more drought-tolerant crops or cover crops during dry periods. Installation of tile drainage may have influenced the frequency of wet periods in VegDRI (particularly in the Northern Glaciated Plains). Although previously not common in the study area (Pavelis 1987), tile drainage has increased in the northern Great Plains in recent years (Cihacek et al. 2012). Management actions might also influence the drought signal measured by the satellite record. For example, fallow land has a different phenological pattern of NDVI than cropped land (Wardlow et al. 2007).

Another potential factor for drought differences among grassland, shrubland, and cropland is preferential site selection for cropland. Land-use decisions are made by managers based on many variables, including expected yields, so cropland is likely to be different from grassland in soil, climate, topography, drainage, and other factors. These factors could contribute to the lower drought frequency observed in croplands in the VegDRI time series, since locations that are less affected by drought are presumably more likely to be converted to cropland.

It is also possible that these observed differences in VegDRI are attributable to the analysis procedure. Since NLCD land cover and ecoregion are inputs to VegDRI, it is conceivable they are affecting drought index values in a way that is detected by this analysis. Also, since VegDRI is a measurement of the anomaly compared to average conditions, it is possible that the difference between the study period (1989-2012) and the averaging period (1989-2008) could affect the drought index.

\subsection{Causes of west-east drought gradient in the northern plains}

In the northern plains, there was a west-east gradient of decreasing frequency and intensity of drought (for all land-cover types), with the Northwestern Great Plains (43) being relatively dry and the Northern Glaciated Plains (46) being 
Earth Interactions - Volume 22 (2018) • Paper No. 17 • Page 20

relatively wet (Figure 7). Western Minnesota and the eastern Dakotas have seen increased precipitation and rising lakes since the 1990s (Millett et al. 2009). Historical drought indices utilized for development of the VegDRI model were normalized to long-term ( $>30 \mathrm{yr}$ ) records (Brown et al. 2008), suggesting that measurements during the study period are wet relative to the earlier record. Precipitation trends in the northwestern plains are not as large as in the northeast of the study area, nor are they as widely discussed, but there is some indication of a slight trend toward increased dryness in the northwestern plains (Sheffield et al. 2012). The west-east pattern was seen in both grassland and (not as strongly) cropland, which can be explained by regional climate patterns but is not consistent with being caused by land-cover classification, VegDRI algorithm implementation, or changes in cropland management. This pattern is less clear during wet periods than during droughts, suggesting that wet periods have been more evenly distributed spatially across the northern plains, whereas droughts have been prevalent more to the west.

\subsection{Land-cover changes through time}

During the period of this study, the land cover across the Great Plains has been relatively stable. Croplands have gradually been increasing since 2005, and larger cities have become larger while smaller cities have been shrinking (Homer et al. 2015). The major forces of change (conversion of grassland to cropland) occurred prior to our study - the Conservation Reserve Program and the 1985 Farm Bill incentivized the removal of land from agricultural production. A study by Drummond et al. (2012) found $8 \%$ overall spatial change in land cover across the Great Plains from 1973 to 2000. The land cover was largely stable, with agricultural land cover declining by $4 \%$, marked mainly by a conversion to grassland.

Within cultivated croplands, a land-use change occurring in the Great Plains has been a change in crop types due to the expansion of soybeans and corn into areas that were previously used for wheat and other small grains production (Lark et al. 2015). It has been hypothesized that this pattern is due to climate change (longer growing seasons and increased precipitation; Kunkel et al. 2013). This may be the case in the northeastern Great Plains, but economic incentives and rapid advances in crop genetics that have resulted in corn and soybean varieties suited to shorter growing seasons and drier conditions are likely to have significantly influenced the increases in corn and soybean production. More drought-tolerant crops might be expected to moderate VegDRI drought severity estimates during dry periods, but comprehensive data on where and when drought-tolerant crops were planted would be needed to test this.

\section{Finall remarks}

In summary, this study found that the overall VegDRI drought fractions for grassland, shrub/scrub, and nonirrigated cultivated crops were generally less than $20 \%$, and cropland had a lower drought fraction of 10\%-13\%. An east-west gradient of increasing drought occurrence across the northern Great Plains was found. The Northern Glaciated Plains (46) had the lowest percentage of drought 
over the study period in nonirrigated cultivated crops and grassland land cover, whereas the highest frequency of drought events was found for grassland in the Northwestern Great Plains (43).

Drought was more frequent for scrub/shrub (nine years) than grassland/herbaceous land cover (five years) or nonirrigated cultivated crops (two years) during the period of the study over the NCA3 region. In smaller-scale examples, in the Northwestern Great Plains (43) grassland, there were 3 times as many dry years as wet years (10 vs 3$)$ and almost double the fractional coverage of dry over wet conditions (21\% vs $11 \%$ ), and cropland had similar frequencies. Also, in the Central Great Plains (27) of the south, drought was more frequent in grassland/ herbaceous land cover than cropland.

The VegDRI drought record of the Great Plains provides insight into interactions between drought and LULC. Climate trends in the northern plains are visible in the VegDRI drought data, with more dryness to the west and more wetness in the east, which is consistent with the recent rise in lake levels in the eastern plains (Mushet et al. 2015).

Although the NCA3 Great Plains region provides a useful geographic framework for investigations of interactions between LULC and climate, the smaller and ecologically defined ecoregions of the Great Plains are more uniform ecologically and climatically. Using ecoregions as a framework for analysis allows separate consideration of differing areas along the edges of the NCA3 region and regions that have unique processes [e.g., Nebraska Sand Hills (44)]. Splitting the Great Plains region into separate northern and southern regions would be helpful for national-level summaries because major ecoregions within the two new regions would be more similar to each other than to ecoregions in the other new region.

Measurements of drought by VegDRI vary by LULC type as well as by location. Grassland experienced drought more frequently than cropland in the VegDRI observations, even within ecoregions. Since VegDRI uses satellite data, weather station observations, and LULC/ecoregion data as inputs, it can be difficult to further disentangle the causes and effects. Further research with these inputs could aid in the investigation of the feedbacks between LULC and climate. Linkages between weather data and satellite measurements are of particular interest because they could help in understanding land-atmosphere interactions.

Acknowledgments. We thank M. Rigge and two anonymous reviewers for their valuable comments and suggestions, which helped to improve this manuscript. We are grateful to many individuals at the USGS Earth Resources Observation and Science (EROS) Center and the National Drought Mitigation Center, University of Nebraska-Lincoln, who have supported the research, development, and operational production of VegDRI. It would be challenging to name the entire crew, but we especially thank T. Tadesse, B. Wardlow, M. Svoboda, M. Hayes, K. Callahan, D. Howard, K. Evenson, and T. Vaughn. Current operational production of VegDRI is funded by the USGS Land Remote Sensing program. Funding for authors Tollerud, Brown, Loveland, and Bliss was provided by the USGS Climate and Land Use Change mission area. Heather Tollerud acknowledges the USGS Mendenhall Postdoctoral program. Work by Norman Bliss was performed under USGS Contract G13PC00028. Rezaul Mahmood received support from NSF Grant AGS1720417. Any use of trade, firm, or product names is for descriptive purposes only and does not imply endorsement by the authors or U.S. government. 
Earth Interactions - Volume 22 (2018) - Paper No. 17 • Page 22

\section{References}

Andreadis, K. M., and D. P. Lettenmaier, 2006: Trends in 20th century drought over the continental United States. Geophys. Res. Lett., 33, L10403, https://doi.org/10.1029/2006GL025711.

Auch, R. F., 2015: Northern Glaciated Plains ecoregion. In Status and trends of land change in the Great Plains of the United States-1973 to 2000, J. L. Taylor et al., Eds., U.S. Geological Survey Professional Paper 1794-B, 69-76, https://doi.org/10.3133/pp1794B.

Bailey, R. G., 1989: Explanatory supplement to ecoregions map of the continents. Environ. Conserv., 16, 307-309, https://doi.org/10.1017/S0376892900009711.

Bradford, J. B., W. K. Lauenroth, I. C. Burke, and J. M. Paruelo, 2006: The influence of climate, soils, weather, and land use on primary production and biomass seasonality in the US Great Plains. Ecosystems, 9, 934-950, https://doi.org/10.1007/s10021-004-0164-1.

Breshears, D. D., and Coauthors, 2005: Regional vegetation die-off in response to global-changetype drought. Proc. Natl. Acad. Sci. USA, 102, 15 144-15 148, https://doi.org/10.1073/ pnas.0505734102.

Brovkin, V., and Coauthors, 2013: Effect of anthropogenic land-use and land-cover changes on climate and land carbon storage in CMIP5 projections for the twenty-first century. J. Climate, 26, 6859-6881, https://doi.org/10.1175/JCLI-D-12-00623.1.

Brown, D. G., and Coauthors, 2014: Land use and land cover change. Climate Change Impacts in the United States: The Third National Climate Assessment, J. M. Melillo, T. C. Richmond, and G. W. Yohe, Eds., U.S. Global Change Research Program, 318-332.

Brown, J. F., and M. S. Pervez, 2014: Merging remote sensing data and national agricultural statistics to model change in irrigated agriculture. Agric. Syst., 127, 28-40, https://doi.org/ 10.1016/j.agsy.2014.01.004.

— B. Wardlow, T. Tadesse, M. Hayes, and B. C. Reed, 2008: The vegetation drought response index (VegDRI): A new integrated approach for monitoring drought stress in vegetation. GISci. Remote Sens., 45, 16-46, https://doi.org/10.2747/1548-1603.45.1.16.

Cihacek, L. J., D. Franzen, X. Jia, R. Johnson, and T. Scherer, 2012: Evaluation of soils for suitability for tile drainage performance. North Dakota State University Rep. SF-1617, 8 pp., https://www.ag.ndsu.edu/pubs/plantsci/soilfert/sf1617tiledrain.pdf.

DeAngelis, A., F. Dominguez, Y. Fan, A. Robock, M. D. Kustu, and D. Robinson, 2010: Evidence of enhanced precipitation due to irrigation over the Great Plains of the United States. $J$. Geophys. Res., 115, D15115, https://doi.org/10.1029/2010JD013892.

de Noblet-Ducoudré, N., and Coauthors, 2012: Determining robust impacts of land-use-induced land cover changes on surface climate over North America and Eurasia: Results from the first set of LUCID experiments. J. Climate, 25, 3261-3281, https://doi.org/10.1175/ JCLI-D-11-00338.1.

Drummond, M. A., 2015: Central Great Plains ecoregion. In Status and trends of land change in the Great Plains of the United States-1973 to 2000, J. L. Taylor et al., Eds., U.S. Geological Survey Professional Paper 1794-B, 19-26, https://doi.org/10.3133/pp1794B.

— , R. F. Auch, K. A. Karstensen, K. L. Sayler, J. L. Taylor, and T. R. Loveland, 2012: Land change variability and human-environment dynamics in the United States Great Plains. Land Use Policy, 29, 710-723, https://doi.org/10.1016/j.landusepol.2011.11.007.

Eidenshink, J., 2006: A 16-year time series of $1 \mathrm{~km}$ AVHRR satellite data of the conterminous United States and Alaska. Photogramm. Eng. Remote Sensing, 72, 1027-1035, https:// doi.org/10.14358/PERS.72.9.1027.

Fensham, R. J., R. J. Fairfax, and D. P. Ward, 2009: Drought-induced tree death in savanna. Global Change Biol., 15, 380-387, https://doi.org/10.1111/j.1365-2486.2008.01718.x.

Foley, J. A., and Coauthors, 2005: Global consequences of land use. Science, 309, 570-574, https:// doi.org/10.1126/science.1111772.

Fry, J. A., and Coauthors, 2011: Completion of the 2006 national land cover database for the conterminous United States. Photogramm. Eng. Remote Sensing, 77, 858-864. 


\section{Earth Interactions - Volume 22 (2018) • Paper No. 17 • Page 23}

Gollehon, N., and W. Quinby, 2000: Irrigation in the American West: Area, water and economic activity. Int. J. Water Resour. Dev., 16, 187-195, https://doi.org/10.1080/ 07900620050003107.

Heim, R. R., 2002: A review of twentieth-century drought indices used in the United States. Bull. Amer. Meteor. Soc., 83, 1149-1166, https://doi.org/10.1175/1520-0477-83.8.1149.

Homer, C., and Coauthors, 2015: Completion of the 2011 National Land Cover Database for the conterminous United States-Representing a decade of land cover change information. Photogramm. Eng. Remote Sensing, 81, 345-354.

HPRCC, 2018: 30-year climate normals (1981-2010). High Plains Regional Climate Center, accessed 3 March 2018, https://hprcc.unl.edu/maps.php?map=Normals.

Ji, L., and A. J. Peters, 2003: Assessing vegetation response to drought in the northern Great Plains using vegetation and drought indices. Remote Sens. Environ., 87, 85-98, https://doi.org/ 10.1016/S0034-4257(03)00174-3.

Kambly, S., 2015: Flint Hills ecoregion. In Status and trends of land change in the Great Plains of the United States-1973 to 2000, J. L. Taylor et al., Eds., U.S. Geological Survey Professional Paper 1794-B, 107-114, https://doi.org/10.3133/pp1794B.

Knapp, A. K., and Coauthors, 2008: Consequences of more extreme precipitation regimes for terrestrial ecosystems. BioScience, 58, 811-821, https://doi.org/10.1641/B580908.

Kumagai, T., H. Kanamori, and T. Yasunari, 2013: Deforestation-induced reduction in rainfall. Hydrol. Processes, 27, 3811-3814, https://doi.org/10.1002/hyp.10060.

Kunkel, K. E., T. R. Karl, D. R. Easterling, K. Redmond, J. Young, X. Yin, and P. Hennon, 2013: Probable maximum precipitation and climate change. Geophys. Res. Lett., 40, 1402-1408, https://doi.org/10.1002/grl.50334.

Lark, T. J., J. Meghan Salmon, and H. K. Gibbs, 2015: Cropland expansion outpaces agricultural and biofuel policies in the United States. Environ. Res. Lett., 10, 044003, https://doi.org/ 10.1088/1748-9326/10/4/044003.

Lauenroth, W. K., I. C. Burke, and M. P. Gutmann, 1999: The structure and function of ecosystem in the central North American grassland region. Great Plains Res., 9, 223-259.

Lawrence, D., and K. Vandecar, 2015: Effects of tropical deforestation on climate and agriculture. Nat. Climate Change, 5, 27-36, https://doi.org/10.1038/nclimate2430.

Livneh, B., and M. P. Hoerling, 2016: The physics of drought in the U.S. central Great Plains. J. Climate, 29, 6783-6804, https://doi.org/10.1175/JCLI-D-15-0697.1.

Loveland, T. R., and R. Mahmood, 2014: A design for a sustained assessment of climate forcing and feedbacks related to land use and land cover change. Bull. Amer. Meteor. Soc., 95, 1563-1572, https://doi.org/10.1175/BAMS-D-12-00208.1.

$\longrightarrow,-$ T. Tatel-Weynand, K. A. Karstensen, K. Beckendorf, N. Bliss, and A. Carleton, 2012: National climate assessment technical report on the impacts of climate and land use and land cover change. U.S. Geological Survey Open-File Rep. 2010-1155, 86 pp., https://pubs.usgs. gov/of/2012/1155/of2012-1155.pdf.

Mahmood, R., and Coauthors, 2014: Land cover changes and their biogeophysical effects on climate. Int. J. Climatol., 34, 929-953, https://doi.org/10.1002/joc.3736.

— R. A. Pielke, and C. A. McAlpine, 2016: Climate-relevant land use and land cover change policies. Bull. Amer. Meteor. Soc., 97, 195-202, https://doi.org/10.1175/BAMS-D-14-00221.1.

Malhi, Y., J. T. Roberts, R. A. Betts, T. J. Killeen, W. Li, and C. A. Nobre, 2008: Climate change, deforestation, and the fate of the Amazon. Science, 319, 169-172, https://doi.org/10.1126/ science.1146961.

Melillo, J., T. C. Richmond, and G. W. Yohe, Eds., 2014: Climate Change Impacts in the United States: The Third National Climate Assessment. U.S. Global Change Research Program Rep., $841 \mathrm{pp}$.

Millett, B., W. C. Johnson, and G. Guntenspergen, 2009: Climate trends of the North American prairie pothole region 1906-2000. Climatic Change, 93, 243-267, https://doi.org/10.1007/ s10584-008-9543-5. 
Earth Interactions - Volume 22 (2018) • Paper No. 17 • Page 24

Mushet, D. M., M. Goldhaber, C. Mills, K. McLean, V. Aparicio, R. B. McCleskey, J. Holloway, and C. Stockwell, 2015: Chemical and biotic characteristics of prairie lakes and large wetlands in south-central North Dakota-Effects of a changing climate. U.S. Geological Survey Rep. 2015-5126, 68 pp., https://doi.org/10.3133/sir20155126.

NOAA NCEI, 2017: Billion-dollar weather and climate disasters: Overview. NOAA National Centers for Environmental Information, https://www.ncdc.noaa.gov/billions/.

Omernik, J. M., 1987: Ecoregions of the conterminous United States. Ann. Assoc. Amer. Geogr., 77, 118-125, https://doi.org/10.1111/j.1467-8306.1987.tb00149.x.

Otkin, J. A., and Coauthors, 2016: Assessing the evolution of soil moisture and vegetation conditions during the 2012 United States flash drought. Agric. For. Meteor., 218-219, 230-242, https://doi.org/10.1016/j.agrformet.2015.12.065.

Palmer, W. C., 1965: Meteorological drought. U.S. Department of Commerce Weather Bureau Research Paper 45, 58 pp., https://www.ncdc.noaa.gov/temp-and-precip/drought/docs/ palmer.pdf.

Pavelis, G. A., 1987: Farm drainage in the United States: History, status, and prospects. Economic Research Service Publ. 1455, 186 pp., https://files.eric.ed.gov/fulltext/ED295043.pdf.

Pervez, M. S., and J. F. Brown, 2010: Mapping irrigated lands at 250-m scale by merging MODIS data and national agricultural statistics. Remote Sens., 2, 2388-2412, https://doi.org/10.3390/ rs2102388.

Phillips, O. L., and Coauthors, 2009: Drought sensitivity of the Amazon Rainforest. Science, 323, 1344-1347, https://doi.org/10.1126/science.1164033.

_ , and Coauthors, 2010: Drought-mortality relationships for tropical forests. New Phytol., 187, 631-646, https://doi.org/10.1111/j.1469-8137.2010.03359.x.

Pielke, R. A., Sr., 2001: Influence of the spatial distribution of vegetation and soils on the prediction of cumulus convective rainfall. Rev. Geophys., 39, 151-177, https://doi.org/10.1029/ 1999RG000072.

— - and Coauthors, 2011: Land use/land cover changes and climate: Modeling analysis and observational evidence. Wiley Interdiscip. Rev.: Climate Change, 2, 828-850, https://doi.org/ 10.1002/wcc.144.

Raz-Yaseef, N., D. P. Billesbach, M. L. Fischer, S. C. Biraud, S. A. Gunter, J. A. Bradford, and M. S. Torn, 2015: Vulnerability of crops and native grasses to summer drying in the U.S. southern Great Plains. Agric. Ecosyst. Environ., 213, 209-218, https://doi.org/10.1016/ j.agee.2015.07.021.

Reid, R. S., R. L. Kruska, N. Muthui, A. Taye, S. Wotton, C. J. Wilson, and W. Mulatu, 2000: Landuse and land-cover dynamics in response to changes in climatic, biological and socio-political forces: The case of southwestern Ethiopia. Landscape Ecol., 15, 339-355, https://doi.org/ 10.1023/A:1008177712995.

Rossum, S., and S. Lavin, 2000: Where are the Great Plains? A cartographic analysis. Prof. Geogr., 52, 543-552, https://doi.org/10.1111/0033-0124.00245.

Saatchi, S., S. Asefi-Najafabady, Y. Malhi, L. E. O. C. Aragão, L. O. Anderson, R. B. Myneni, and R. Nemani, 2013: Persistent effects of a severe drought on Amazonian forest canopy. Proc. Natl. Acad. Sci. USA, 110, 565-570, https://doi.org/10.1073/pnas.1204651110.

Sayler, K. L., 2015: Northwestern Great Plains ecoregion. In Status and trends of land change in the Great Plains of the United States-1973 to 2000, J. L. Taylor et al., Eds., U.S. Geological Survey Professional Paper 1794-B, 35-41, https://doi.org/10.3133/pp1794B.

Schwinning, S., and O. E. Sala, 2004: Hierarchy of responses to resource pulses in arid and semiarid ecosystems. Oecologia, 141, 211-220, https://doi.org/10.1007/s00442-004-1520-8.

Shafer, M., and Coauthors, 2014: Great Plains. Climate Change Impacts in the United States: The Third National Climate Assessment, J. M. Melillo, T. C. Richmond, and G. W. Yohe, Eds., U.S. Global Change Research Program, 441-461.

Sheffield, J., K. M. Andreadis, E. F. Wood, and D. P. Lettenmaier, 2009: Global and continental drought in the second half of the twentieth century: Severity-area-duration analysis and 
Earth Interactions - Volume 22 (2018) • Paper No. 17 • Page 25

temporal variability of large-scale events. J. Climate, 22, 1962-1981, https://doi.org/10.1175/ 2008JCLI2722.1.

— E. F. Wood, and M. L. Roderick, 2012: Little change in global drought over the past 60 years. Nature, 491, 435-438, https://doi.org/10.1038/nature11575.

Stier, M. P., and B. A. Friesen, 2015: Edwards Plateau ecoregion. In Status and trends of land change in the Great Plains of the United States-1973 to 2000, J. L. Taylor et al., Eds., U.S. Geological Survey Professional Paper 1794-B, 133-140, https://doi.org/10.3133/pp1794B.

Tadesse, T., B. D. Wardlow, J. F. Brown, M. D. Svoboda, M. J. Hayes, B. Fuchs, and D. Gutzmer, 2015: Assessing the vegetation condition impacts of the 2011 drought across the U.S. southern Great Plains using the vegetation drought response index (VegDRI). J. Appl. Meteor. Climatol., 54, 153-169, https://doi.org/10.1175/JAMC-D-14-0048.1.

Taylor, J. L., 2015a: Northwestern Glaciated Plains ecoregion. In Status and trends of land change in the Great Plains of the United States-1973 to 2000, J. L. Taylor et al., Eds., U.S. Geological Survey Professional Paper 1794-B, 77-86, https://doi.org/10.3133/pp1794B.

_ 2015b: Nebraska Sand Hills ecoregion. In Status and trends of land change in the Great Plains of the United States-1973 to 2000, J. L. Taylor et al., Eds., U.S. Geological Survey Professional Paper 1794-B, 27-34, https://doi.org/10.3133/pp1794B.

Tilman, D., and J. A. Downing, 1994: Biodiversity and stability in grasslands. Nature, 367, 363365, https://doi.org/10.1038/367363a0.

Tomer, M. D., and K. E. Schilling, 2009: A simple approach to distinguish land-use and climatechange effects on watershed hydrology. J. Hydrol., 376, 24-33, https://doi.org/10.1016/ j.jhydrol.2009.07.029.

USGS, 2015: Vegetation drought response index (VegDRI). U.S. Geological Survey, https://doi.org/ 10.5066/F7SN07WV.

Vicente-Serrano, S. M., and Coauthors, 2013: Response of vegetation to drought time-scales across global land biomes. Proc. Natl. Acad. Sci. USA, 110, 52-57, https://doi.org/10.1073/ pnas. 1207068110.

Wang, J., and Coauthors, 2009: Impact of deforestation in the Amazon basin on cloud climatology. Proc. Natl. Acad. Sci. USA, 106, 3670-3674, https://doi.org/10.1073/pnas.0810156106.

Wardlow, B., S. Egbert, and J. Kastens, 2007: Analysis of time-series MODIS $250 \mathrm{~m}$ vegetation index data for crop classification in the U.S. central Great Plains. Remote Sens. Environ., 108, 290-310, https://doi.org/10.1016/j.rse.2006.11.021.

Wells, N., S. Goddard, and M. J. Hayes, 2004: A self-calibrating Palmer Drought Severity Index. J. Climate, 17, 2335-2351, https://doi.org/10.1175/1520-0442(2004)017<2335: ASPDSI $>2.0 . \mathrm{CO} ; 2$.

Wilhelmi, O. V., and D. A. Wilhite, 2002: Assessing vulnerability to agricultural drought: A Nebraska case study. Nat. Hazards, 25, 37-58, https://doi.org/10.1023/A:1013388814894.

Earth Interactions is published jointly by the American Meteorological Society, the American Geophysical Union, and the Association of American Geographers. For information regarding reuse of this content and general copyright information, consult the AMS Copyright Policy (www.ametsoc.org/PUBSReuseLicenses). 